\title{
TAFSIR REALIS TERHADAP MAKNA DAN SIMBOL ALQURAN BAGI MASYARAKAT KABUPATEN PROBOLINGGO
}

\author{
A Rafiq Zainul Mun'im \\ SekolahTinggi Agama Islam Nahdlatul Ulama Jakarta \\ Alamat: Jl. Taman Amir Hamzah No. 5 Jakarta Pusat 10430 \\ E-mail: arafiqzm1@gmail.com
}

\begin{abstract}
Realist Interpretation and Symbolic Meaning of the Quran for the Society of Probolinggo Regency. All Moslem scholars believe that people have own ways to respond, interact, and function Quranic verses within their lives. Their effort is only to maintain the majesty of the Quran. Therefore, this study will examine how does the symbolization of Quranic verses has functions for, how do they elucidate and interpret, how do their interpretation and symbolization of Quranic verses take a position in Quranic discourse, especially in Probolinggo. The qualitative paradigm was chosen to clarify those questions. Meanwhile, the approach to data is Turner's processional approach of symbolism and Levi Strauss' structuralism. Through this discussion, the result of research concluded that the symbolization of Quranic verses has four functions, mainly (1) source of religious teaching; key element of ritual and ceremonial activities; ornament of calligraphy; and mystical medium, (2) symbolization of verses indicates Probolinggo people's stance in using Quran; the meaning of symbolized verses is possible to trace from their consciousness and unconsciousness, and (3) interpretation and symbolization of Quranic verses take a position in the light of realist interpretation and meaningful interpretation as well as the living Quran, which have implied not only theoretical study of Quranic verses, but also practical function for society in the real life.
\end{abstract}

Keywords: function; symbol; meaning; the Quran; society.

\begin{abstract}
Abstrak: Tafsir Realis terhadap Makna dan Simbol Alquran bagi Masyarakat Kabupaten Probolinggo. Cendekiawan Muslim percaya bahwa setiap orang memiliki karater sendiri dalam merespons, berinteraksi, dan memfungsikan ayatayat Alquran dalam kehidupan mereka. Upaya yang ditempuh semata-mata ingin memelihara keagungan Alquran. Oleh sebab itu, penelitian ini akan mengkaji bagaimana masyarakat Kabupaten Probolinggo dalam menafsirkan simbolisasi makna ayat-ayat Alquran. Paradigma kualitatif dipilih untuk mengklarifikasi pertanyaan tersebut. Sementara itu, pendekatan terhadap data adalah pendekatan prosesual simbologi Turner dan strukturalisme Levi Strauss. Melalui pembahasan ini, hasil penelitian menguraikan bahwa (1) simbolisasi ayat-ayat Alquran memiliki empat fungsi, yaitu sumber ajaran agama; elemen penting dalam kegiatan ritual dan seremonial; ornamen kaligrafi; dans arana (media) mistis, (2) simbolisasi ayat-ayat tersebut mengindikasikan sikap orang-orang Probolinggo dalam menggunakan Alquran, (3) posisi pemaknaan dan simbolisasi ayat-ayat Alquran pada masyarakat Probolinggo berada dalam definisi tafsir realis sebagai bagian dari the living Qur'ân, yang tidak hanya menyiratkan kajian teoretis tentang ayat-ayat Alquran, tetapi juga fungsi praktis bagi masyarakat dalam kehidupan nyata.
\end{abstract}

Kata kunci: tafsir realis; fungsi; simbol; makna; Alquran; masyarakat.

\section{Pendahuluan}

Adalah term Living Qur'ân atau living dialectical-interpretation of sacred verse', sebutan

Sekedar untuk menegaskan kembali, kata 'Living Quran' bermakna; sacred-text (teks suci) yang hidup di dalam masyarakat Islam. Sedang produk-produk penafsiran terhadap teks tersebut disebut "living Interpretation". Lihat; Sahiron Syamsudin, "Ranah-Ranah Penelitian dalam Alquran dan Hadis" Kata Pengantar, dalam M. Mansur, Metodologi Living Qur'an dan Hadis, (Yogyakarta: Teras, 2007), xviii. Di dalam buku yang sama, M. Mansur menyatakan kalau Living Quran merupakan paling cocok untuk mendeskripsikan keseluruhan diskursus yang akan penulis bingkai dalam artikel ini. Sama seperti penggagas pendekatan ini, ${ }^{2}$

bentuk dialektika fenomena masyarakat dan kandungan makna/simbol yang ada di dalam Alquran, yang kemudian, diinterpretasikan ulang berasaskan pada pemahaman yang relevan pada kebutuhan hari ini. Lihat M. Mansur, Metodologi Living Qur'an dan Hadis, (Yogyakarta: Teras, 2007), h. 5.

${ }^{2}$ Bagi penulis ada dua alasan kenapa pendekatan ini dirancang dan diperkenalkan sebagai sebuah disiplin kajian Alquran dan hadis. Pertama, ada jarak waktu, tempat, dan kondisi sosial dimana teks Alquran dan hadis dilahirkan sebagai 
tujuan penulis ialah mendeskripsikan bagaimana makna, fungsi, dan posisi Alquran dalam kehidupan masyarakat, terkhusus di wilayah Probolinggo. ${ }^{3}$ Makna yang merupakan hasil dari pemahaman seseorang terhadap Alquran. Fungsi adalah cara masyarakat untuk menghadirkan Alquran dalam kehidupan sehari-hari. Sedangkan posisi bermakna letak dimana Alquran ditampilkan oleh masyarakat. Pastinya, karena kajian ini sudah menjadi tren di kalangan pakar tafsir dan hadis, maka penulis membutuhkan pendekatan yang berbeda. Untuk membuktikannya, penulis akan menunjukkan hasil riset terdahulu terkait tema living Qur'ân tersebut: Muhammad Ali, ${ }^{4}$ Ahmad Atabik, ${ }^{5}$ Hamam Faizin, ${ }^{6}$

guidance terhadap umat Islam. Maka dari itu, menghidupkan kembali nilai-nilai subtantif serta visioner dari sebuah teks akan lebih menjadikan Alquran berkesesuaian dengan zaman di masyarakat. Kedua, memberikan landasan pembenar secara ilmiah, bahwa re-intrepretasi teks berbasis kearifan lokal (cultural based), bisa digunakan laiknya dilakukan oleh para penafsir-penafsir terdahulu yang memiliki zaman atau era berbeda dengan Nabi Muhammad Saw.

3 Pilihan penulis terhadap Kabupaten Probolinggo sebagai lokus kajian living Qur'an ini tidak bisa dilepaskan oleh empat alasan penting; pertama, masih kuatnya tradisitradisi keislaman; apakah cultural ataupun yang murni dari pemahaman terhadap ajaran Islam. Kedua, terdapat dua pondok pesantren besar yang memiliki pengaruh signifikan pada bagaimana masyarakat muslim di daerah tersebut bersikap. Ketiga, akan ada konstestasi politik dimana agama selalu hadir khususnya di wilayah Tapal Kuda di Jawa Timur. Keempat, ada nilai kedekatan penulis (sebagai seorang insider) sehingga penulis dapat menelusuri makna subtantif dari cara bicara, leksiologi kebahasaan yang digunakan, serta model-model interpretasi masyarakat menggunakan bahasa daerah asal penulis (baca; Madura). Lihat: Ali Hasan Siswanto "Relasi Politik Kyai di Daerah Tapal Kuda Jawa Timur," Penelitin individu Dosen (Surabaya: Lembaga Penelitian IAIN Sunan Ampel, Tahun 2011), h. 61.

${ }^{4}$ Muhammad Ali, "Kajian Naskah dan Kajian Living Qur'an dan Living Hadis", dalam Journal of Qur'an and Hadith Studies, Vol. 4, No 2 Tahun 2015 147-167. Penelitian ini berbasis penelitian literatur berbasis pada karya pengkaji Islam, mufassir dan muhaddis baik di Timur, termasuk Indonesia dan Barat. Tujuan akhir penelitian ini sekedar untuk menjabarkan beberapa kategori produk ilmiah tersebut, sebagai perwujudan bahwa dua pendekatan (baca; living Qur'an dan hadis) itu memang sudah pernah dilakukan.

5 Ahmad Atabik, "The Living Quran: Potret Budaya Tahfiz Alquran Nusantara”, dalam Jurnal Penelitian,Vol. 8 No 1 Februari 2014, 162. Penelitian ini ingin menunjukkan reinkarnasi budaya menghafal Alqurandi kalangan para santri berdasarkan beberapa pendekatan dan metode menghafalnya. Ruang lingkup penelitian ini sangat luas. Sebab model kajiannya bermodel fenomenalisme budaya menghafal al Quran, termasuk apresiasi negara/perguruan tinggi terhadap para penghafal Alquran.

${ }^{6}$ Hamam Faizin, "Mencium dan Nyunggi Alquran Upaya Pengembangan Kajian Alquran Melalui Living Qur'an”, dalam Jurnal Suhuf, Vol. 4 No 1, Tahun 2011, h. 23. Sama seperti Muhammad Ali, kajian ini lebih mengarahkan pada kajian teks
Siti Fauziyah,7 Heddy Shri Ahimsa Putra, ${ }^{8}$ Moh. Muhtador, 9 dan Nur Faizah, ${ }^{10}$ Ragam riset ini kalau penulis kategorisasikan bisa menjadi tiga topik; pertama, kajian naskah dan polarisasi model pendekatan living Qur'ân. Kedua, berbentuk kajian antropologi dalam melihat dialektika kandungan ajaran Alquran dan kehidupan masyarakat. Ketiga, memaknai Alquran menggunakan pendekatan strukturalisme (kajian kebahasaan).

Berdasarkan riset terdahulu tersebut, tentu, penulis tidak akan mengulangi pola kajian serupa; kendati penulis tidak akan melepas bahwa model paradigma antropologi ${ }^{11}$ merupakan

pemaknaan Alquran di kalangan ulama' dan tokoh masyarakat; apakah itu memiliki otoritas (baca; mufassir professional) atau tidak dalam menelaah makna-makna yang terkandung di dalam Alquran. Pada kesimpulannya, dia hanya mempertegas bahwa model pendekatan living Quran itu penting, karena akan menjadikan kesadaran bermasyarakat akan Islam lebih dekat. Terlebih apabila Alquran dihadirkan sebagai wujud pembelaan terhadap kehidupan mereka yang tertindas, seperti yang digagas oleh Farid Esack. Sekedar catatan, konten tulisan ini, tidak sesuai dengan judul yang disebut. Kendati, secara sistematika dan model postulasi, tulisan ini cukup otoritatif membicarakan makna konsep living Quran dan hadis.

7 Siti Fauziyah, "Pemaknaan ayat Alquran dalam mujahadah: Studi Living Qur'an di PP al Munawwir Krapyak komplek al Kandiyas", dalam Jurnal Penelitian, Vol. 8 No. 1 Tahun 2014

${ }^{8}$ Heddy Shri Ahimsa Putra, "The Living Alquran: Beberapa Perspektif Antropologi”, dalam Jurnal Walisongo, Vol. 20, No.1, Mei 2012, h. 235.

9 Moh. Muhtador, "Pembacaan Alquran Surat-Surat Pilihan di Pondok Pesantren Putri Daar al Furqon Anggalan Kudus (Studi Living Qur'an)", dalam Jurnal Studi IImu-IImu Alquran dan Hadis, Vol. 15, No. 1, Januari 2014, h 159

${ }^{10}$ Nur Faizah, "Ayat-Ayat Tentang Relasi Laki-Laki Dan Perempuan Dalam Alquran (Analisis Struktural Levi-Strauss)", dalam Jurnal Al Ahwal, Vol 8, No 2 Tahun 2015, h. 111.

${ }^{11}$ Masdar Hilmy dan Akh. Muzakki menyatakan bahwa concern antropologi dalam kajian Islam adalah produk yang mengejewantah dan masyarakat yang mengambil ajaran tersebut sebagai dasar bagi ekspresi keseharian mereka. Ekspresi tersebut kemudian menyatu dalam kebudayaan secara keseluruhan. Lihat; Akh. Muzakki \& Masdar Hilmy, Dinamika Baru Studi Islam (Surabaya : Arkola, 2005), h. 160. Sama halnya dengan Rossalind J. Hackett mendeskripsikan bahwa "Anthropology enjoys an ongoing dialectical tension between its scientific and humanistic sides...'Emphasis on culture and recognition of the subjective aspect of interpretation link anthropology to the humanities,... Religious beliefs and concepts as the product of particular social conditions, rather than in intellectualist terms. Lebih lanjut lihat Rosalind I. J. Hackett, Anthropology of Religion, dalam John R. Hinnells. (ed) The Routledge Companion to the Study of Religion (London: Rutledge, 2005), h.145. Dan jika dilihat pada kajian terdahulu di atas, tampak sekali hampir semua penelitian menunjukkan aspek yang mengejawantah di masyarakat tentang bagaimana posisi Alquran di masyarakat. Kendati adapula yang menggalinya secara kajian terminologis dan fenomenologis. 
cara efektif untuk menilai relasi Alquran dan masyarakat. Meskipun secara distingtif nantinya, penulis akan menambahkan bagaimana model interpretasi simbolik menurut Victor W. Turner ${ }^{12}$ dan Levi Strauss' ${ }^{13}$. Penggabungan dua peneliti kebudayaan ini, diharapkan akan menghasilkan kajian yang lebih menyeluruh. Berasas pada asumsi dan kerangka teori tersebut pula, maka penulis akan membagi tulisan ini menjadi tiga topik penting; pertama, fungsi-fungsi simbolisasi ayat-ayat Alquran bagi masyarakat Probolinggo; kedua, bagaimana pemaknaan masyarakat Probolinggo terhadap simbolisasi dari ayat-ayat Alquran; ketiga, bagaimana posisi makna dan simbolisasi ayat-ayat Alquran tersebut dalam diskursus Alquran. Dari tiga fokus ini, penulis akan mengkontekskannya pada tiga lokus yang berbeda; lembaga pendidikan, masyarakat umum, dan tampilan simbolik di institusi sosial kemasyarakatan. Tujuannya untuk lebih memperluas cakupan kajian persepsional terkait fungsi Alquran di dalam kehidupan masyarakat. ${ }^{14}$

${ }^{12}$ Victor W Turner adalah seorang cultural anthropologist. Salah satu atifak pemikiran Turner yang paling monumental adalah tentang simbolism and technique, myth and ritual, dan social drama and luminity . Lihat; Victor W Turner, The Ritual Process; Stucture and anti-Structure, (Chicago, tp, 1969). Gagasan panjang dia tentang kajian antropologi pada tulisan ini akan penulis gunakan untuk membentuk sudut pandang bagaimana masyarakat Probolinggo membentuk simbolisasi terhadap Alquran dalam bingkai pemahaman yang ditransformasikan menjadi bagian dari umat Islam.

${ }^{13}$ Claire Jacobson, penerjemah buku structural-anthropology karya Levi-Strauss, mengkategorikan pemikiran Levi-Strauss sebagaimana statement berikut: "Levi-Strauss has long been one of chief exponent of the structural method; he considers the relations among phenomena, rather than the nature of the phenomena themselves, and the systems into these relations enter, He persuasively argues that the attainment of a general science of man is contingent on structural considerations, which much include unconscious as well as conscious social process, and he time and again develops his thesis in dealing with some major aspect of culture; language, kinship, social organization, magic, religion, and art." Lihat; Levi Strauss, Structural Anthropology, terj, Claire Jacobson \& B G Schoepf (New York; Basic Book Inc, 1963), x. Berdasarkan pada konsep ini, maka sebuah pemaknaan di dalam masyarakat tentu tidak akan sederhana. Ada banyak aspek yang harus ditafsirkan agar bisa menjadikan konsesinya berbasis kesadaran, magic, atau bahkan hanya sekedar mengikuti ritus yang berkembang di dalam masyarakat. Maka dari itu, untuk menterjemahkan fenomena yang ada di Probolinggo penulis membutuhkan kerangka teori antropologi Strauss sebagai alat menilainya.

14 Howard M. Federspiel dalam bukunya menjelaskan bahwa di sebagian daerah di Indonesia memiliki tradisi membaca Alquran bersama-sama dalam keluarga, bahkan fenomena membaca Alquran bersama dalam keluarga ini menjadi tanda

\section{Metode Penelitian}

Dalam upaya mempostulasi tiga fokus riset di atas, penulis akan menggunakan metode kualitatif sebagai prosedur penelitian. ${ }^{15}$ Sedangkan jenis penelitian ini adalah studi kasus, maka dalam penelitian ini dilakukan secara intensif, terinci dan mendalam terhadap suatu organisasi, lembaga atau gejala tertentu. ${ }^{16}$ Sesuai dengan karakteristik yang desainnya disusun secara sirkuler, maka penelitian ini menggunakan tiga tahapan, yaitu: (1) description, (2) reduction, dan (3) selection. ${ }^{17}$ Penelitian ini menghasilkan data deskriptif berupa ungkapan seseorang baik tertulis maupun ucapan atau perilaku yang diamati. ${ }^{18}$ Oleh sebab itu, maka sumber data yang digunakan dalam penelitian ini adalah dokumen dan masyarakat Muslim Probolinggo atau hasil penelitian yang pernah dilakukan oleh peneliti terdahulu serta literaturliteratur yang berkaitan dengan masalah tersebut untuk membantu pemahaman kajian ini sehingga menjadi jelas dan terinci. Analisis data dalam penelitian ini dimaksudkan sebagai proses menyusun, mengkategori data, dan mencari pola atau tema dengan maksud untuk memahami maknanya. Analisis data merupakan proses

akan ketaatan dalam beragama. Lihat: Howard M. Federspiel, Kajian Alquran di Indonesia dari Mahmud Yunus Hingga Qurash Shihab (Bandung; Mizan, 1996), h. 197-205. Bandingkan dengan Zainal Abidin Yang menjelaskan mengenai keutamaan dan faedah membaca Alquran yang bisa mendapatkan kenikmatan membaca Alquran ketika dia telah membacanya sampai khatam. Lihat Zainal Abidin S. Seluk-beluk Alquran(Jakarta; Rineka Cipta, 1992), h. 152-163.

15 Dalam penelitian kualitatif, jenis datanya berupa pernyataan-pernyataan (kata-kata) yang disampaikan oleh informan sesuai dengan pertanyaan yang diajukan dalam penelitian. Di samping itu ada jenis data hasil observasi dan dokumentasi yang diperoleh di lapangan, berupa perilaku subjek (manusia) yang diamati dan naskah-naskah dokumen yang menggambarkan gejala atau fenomena Alquran di tengahtengah kehidupan masyarakat Probolinggo. Berdasarkan jenisnya, data penelitian ini adalah manusia dan non-manusia. Sumber data manusia yaitu masyarakat Probolinggo dengan menggunakan teknik snowball sampling, yaitu mengidentifikasi dan mewawancarai seseorang yang memiliki karakteristik data yang diperlukan. Sedangkan sumber data non-manusia berupa dokumen tertulis atau tergambar. Lihat Suharsimi Arikunto, Prosedur Penelitian Suatu Pendekatan Praktek, Cet. XI (Jakarta: Rineka Cipta, 1998), 130.

${ }^{16}$ Suharsimi Arikunto, Prosedur Penelitian..., h. 131

17 Nasution, Metodologi Penelitian Naturalistik Kualitatif, (Bandung: Transtinto, 1996).

${ }^{18}$ Bogdan dan Steven, Introduction to Qualitative Research; A Phenomenological Approach to The Social Sciences (New York: John Wiley \& Sons Inc., 1975). 
bertanya-menemukan (question discovery). Prosedur dalam analisis data yang disarankan oleh Miles dan Huberman dan telah digunakan dalam penelitian ini adalah: reduksi data, display data, kesimpulan sementara dan verifikasi. ${ }^{19}$

\section{Pembahasan Penelitian}

Sesuai dengan landasan, kerangka teori, dan metode penelitian yang sudah diungkapkan di atas, maka pada bagian ini penulis akan membincangkan hasil riset penulis terhadap posisi Alquran di kalangan umat Islam yang tinggal di Kabupaten Probolinggo. Komposisi pembahasannya adalah pertama, penulis akan menjelaskan fungsi Alquran di dalam masyarakat. Kedua, memaknai fungsi tersebut, menggunakan pemikiran antropologi cultural and structural Turrner dan Levi-Strauss terhadap simbol qurani yang ditampilkan. Terakhir, adalah pemaknaan ulang penulis terhadap living Qur'ân dalam konteks dan konstestasi masyarakat Probolinggo.

\section{Pendekatan Fungsional Alquran di Probolinggo}

Sesuai asumsi awal penulis terkait fungsi Alquran, riset ini menghasilkan bahwa fungsi Alquran sebagai; pertama, sebagai sumber ajaran Islam. Kedua, bagian dari ritual dan seremoni di lingkungan masyarakat. Ketiga, simbolisasi dalam bentuk kaligrafi. Keempat, sebagai sarana mistis. Berikut ini adalah postulasi faktual tersebut:

\section{a. Ayat-ayat Alquran sebagai Sumber Ajaran Agama}

Salah satu cara melihat fenomena Alquran sebagai ajaran agama, (bisa bandingkan dengan penelitian terdahulu yang penulis kutip), adalah dengan menginstitusionalisasi kajian; apakah itu dalam bentuk lembaga pendidikan, masjid, majelis taklim, atau struktur kelompok masyarakat. Di Probolinggo, setidaknya ada Pondok Pesantren Nurul Jadid, Pondok Pesantren Zainul Hasan, dan pesantren-pesantren kecil lainnya, yang dapat menfungsikan keberadaan Alquran sebagai sumber ajaran agama Islam. Maka dari itu,

${ }^{19}$ Miles \& Huberman, Qualitative Data Analysis, (London: SAGE Publications, 1984), h. 20. penulis akan mengambil satu sampel penelitian untuk menunjukkan bahwa Alquran sebagai sumber ajaran, yakni; di Pondok Pesantren Nurul Jadid Paiton (selanjutnya disingkat PP. Nurul Jadid). Alasan pemilihan ini sederhana, karena selain diajarkan melalui kitab tafsir klasik karya ulama' terdahulu, pendiri, pengasuh, dan pengurus pondok pesantren ini juga melakukan rekontekstualiasi pada proses transmisi pengetahuannya, baik terhadap santri ataupun masyarakat sekitar. ${ }^{20}$

Dari sisi produk teks yang dihasilkan di pondok pesantren ini bisa dilihat dari karya KH. Zaini Mun'im di Pesantren Nurul Jadid. Penulis bisa mengklaim bahwa karya ini adalah satu-satu karya tafsir yang ada di Probolinggo. Corak penafsiran yang dilakukan oleh KH. Zaini Mun'im tidak jauh berbeda dengan model tafsir al-Jalâlaîn. Artinya, seperti tafsir al Mufradât (tafsir secara kebahasaan). Karya KH. Zaini Mun'im ini diberi nama "Tafsir al-Qur'ân al- 'Azhim". Namun demikian, di kalangan santri produk tafsir ini dikenal sebagai Tafsir Alquran bi al-Imla'. Sebab dalam pengajarannya, KH. Zaini Mun'im mendiktekan setiap makna yang sudah dikajinya kepada seluruh santri yang belajar di PP. Nurul Jadid. ${ }^{21}$ Tafsir al-Qur'ân bi al-Imla' ini adalah sebuah pengajian tafsir yang rutin dilaksanakan pada siang hari dan bertempat di Masjid Jami' PP. Nurul Jadid. Pengajiannya merupakan pengajian dengan menggunakan beberapa metode diantaranya adalah metode wathonan (didekte oleh guru) dan sorogan (santri membaca di depan guru). Jadi, setelah KH. Zaini Mun'im mendikte, beliau menyuruh beberapa murid untuk membaca dan memberikan arti secara bergantian dan beliau turut mengedit kebenarannya.

Adapun aktifitas pengkajian tafsir Alquran yang diselenggarakan pengasuh PP Nurul Jadid,

${ }^{20}$ Lihat A. Rafiq Zainul Mun'im, Tafsir Surat al-Fatihah KH. Zainul Mun'im (Yogyakarta: Forstudia kerja bareng PP. Nurul Jadid, 2004), 37. Adapula Karya Khorul Muttaqin yeng mengkaji bagaimana Transmisi Kajian Kitab Tafsir Jalalain di Pondok Pesantren oleh KH. Zuhri Zaini sebagai Pengasuh Pondok Pesantren. Lihat; Khorul Muttaqin, Pengajian Tafsir Jalalain di Pondok Pesantren Nurul Jadid dalam Menjawab Problem Sosial-Keagamaan Kontemporer, Skripsi, Fakultas Ushuludin Jurusan Tafsir Hadis, IAIN Sunan Ampel Surabaya, Tahun 2009).

${ }^{21}$ A. Rafiq Zainul Mun'im, Tafsir Surat al-Fatihah..., h. 39. 
diselenggarakan di Musholla Riyadlus Sholihin. Pilihan penempatan ini ialah untuk membiasakan para mahasiswa santri dan pengurus pesantren, terhadap pemaknaan ulang Alquran yang yang relevan dengan kondisi modern. Dialektikaprogresif pemikiran kiai dan teks Tafsir al-Jalâlaîn yang terkategori sederhana, bisa menjadi landasan bertindak para santri menghadapi persoalan keislaman kontemporer di Indonesia. Misalnya disaat KH. Zuhri Zaini melakukan perluasan makna dari kata kafir, sebagai bentuk respon terhadap dinamika hari ini, dengan non-Muslim yang membangkang terhadap konsensus bersama. Atau disaat menterjemahkan ayat Q.S. al-Kâfirûn [109]: 1-6, sebagai wujud ideal relasi antara Muslim dan non-Muslim, dimana menurut beliau kata agamamu agamamu, agamaku adalah agamaku, merupakan sebuah wujud penghormatan terhadap keyakinan agama orang lain, dst. Dalam penafsirannya, juga dipaparkan bahwa Islam bisa memperlakukan non-Muslim, baik agama Kristen, Katolik, Hindu, Budha dan lain sebagainya. Islam juga mengakui eksistensi agama-agama tersebut karena Islam membawa sebuah sistem nilai (ajaran) inklusif yang untuk mengakui keberadaan agama di luar Islam dan menghormati semua pemeluk agama di luar Islam. ${ }^{22}$

Tampaknya, relasi mutual antara kiai, santri, dan masyarakat juga dimanfaatkan oleh Lora (sebutan untuk putera kiai atau menantu kiai yang masih muda di daerah Tapal Kuda, atau Gus di daerah Jawa umumnya), yang juga mengadakan pengkajian dan pengajian keagamaan berbasis pada Alquran. Terlebih, bagi para Lora yang pondok/asrama santrinya berdampingan dengan masyarakat umum. Misalnya, di asrama Ma'had 'Aly Al-Amiri, yang diasuh oleh Ra Romzi al Amiri Mannan. Di tempat ini, pengajian tafsir Alquran dilaksanakan pada setiap malam selasa dan setiap hari di pagi hari kepada santri dan masyarakat yang ikut berjemaah di Mushala tersebut. Tema dan topik yang dikaji tidak ditentukan. Namun, perspektif tafsir dan hadis selalu dikemukakan untuk melegitimasi sikap keislaman di dalam

${ }^{22}$ Lihat Khoirul Muttaqin, Pengajian Tafsir Jalalain, 123. Berdasarkan hasil parsipasi penulis di Pondok Pesantren tersebut, pengajian ini masih berlanjut hingga sekarang. kehidupan sehari-hari. ${ }^{23}$ Sama seperti Ra Romzi, begitu masyarakat Karang Anyar menyapa dia, Ra Hefni memiliki dimensi yang lebih kuat untuk dikatakan menghidupkan Alquran di wilayah Zaid Bin Tsabit (Gang K). Pondok yang terletat paling Barat PP. Nurul Jadid ini merupakan pondok santri tahfidz, dan sering diundang masyarakat sekitar untuk melakukan seremoni hataman/semaan Alquran di wilayah sekitar. Selain itu juga, Ra Hefni mengadakan pengajian sehabis maghrib terkait makna-makna yang dikandung Alquran yang diikuti oleh masyarakat sekitar dan pengajian ini tetap berlanjut hingga saat ini. ${ }^{24}$

Di luar pesantren, ustaz Masduki (seorang guru dan pengurus MWC NU Paiton) membuat rangkuman kitab tafsir al-Jalâlaîn dan memberi nama kitab kecil itu "al-Muqtathafat". Kepada penulis dia menyatakan bahwa kitab dia sedang diajarkan dan dikaji oleh siswa madrasah tsanawiyah di PP. Nurul Jadid dan di mushola masyarakat di sekitar Paiton. Terkait dengan konten kitab itu, dia menuturkan:

"... para siswa hari itu agak sulit diajak untuk berfikir yang tidak realistis dan kontekstual... Melalui buku ini saya berharap santri mampu memahami Alquran melalui cara yang paling sederhan saja. Seperti ketika menafsirkan surat al-Baqarah [2]: 261, bahwa orang yang memberi sedekah, maka dia akan mendapatkan balasan sebanyak 700 kali lipat. sebagaimana bunyi ayat dari sebuti benih menjadi tujuh bulir dan dimasing-masing bulir sebanyak seratus biji $(1 X 7 X 100=700)$. Apabila dia memberi sedekah sebanyak Rp. 1.000 maka dia akan mendapatkan gantinya dari Allah sebanyak Rp. 700.000, dengan hitungan matematis, yaitu 1000 X 7 X $100=700.000$, baik di dunia maupun di akhirat, karena Allah Swt tidak menjelaskan bahwa kelipatan itu di dunia saja, atau di akhirat saja. Bentuk kelipatan yang diberikan oleh Allah Swt sebanyak 700.000 ini bisa berbentuk rezeki yang tidak terduga, atau terntundanya musibah yang apabila musibah itu terjadi, akan mencapai nominal sebanyak 700.000 tersebut." 25

${ }^{23}$ Wawancara kembali dengan KH. Ramzi, pada tanggal 10 Juni 2017,

${ }^{24}$ Wawancara kembali dengan $\mathrm{KH}$. Hefni, pada tanggal 13 Maret 2017

${ }^{25}$ Wawancara dengan Masduki, pada tanggal 14 Maret 2012 
Keluar dari paradigma institusional, di masyarakat Probolinggo sendiri, seperti yang hari ini terjadi, Alquran tampak masih layak dipertimbangkan sebagai strategi politik seorang calon kepala daerah untuk mengalahkan lawannya. Lima tahun yang lalu, diskursus antara Gender, Alquran, dan kepemimpinan perempuan ramai diperbincangkan di ruang publik. Maklum, salah satu calon yang berkontestasi adalah seorang perempuan, ibu Pupur Tantrianasari. Meski sudah dihantam berbagai isu berbasis keagamaan, tampaknya, mereka yang melakukan penafsiran kontekstual terhadap ayat-ayat kepemimpinan dan dominasi laki-laki kalah dibandingkan para kiai atau tokoh masyarakat yang menafsirkan berbeda. Di tahun politik ini, incumbent sudah mulai mengantisipasi dengan menggandeng ketua MUI Kabupaten Probolinggo, untuk melakukan legitimasi kepemimpinannya. Dia 'sedikit khawatir' isu-isu terkait kepemimpinan perempuan kembali digunakan untuk menggerus suara basisnya. Namun yang namanya strategi politik memang sulit dibaca, hari ini, para lawan politiknya tidak lagi menggunakan paradigma relasi perempuan dan gender, tapi lebih spesifik pada sosok tantri itu sendiri. Misalnya, tulisan opini seorang masyarakat yang menyebutkan bahwa seorang Bupati harus bisa membaca Alquran. ${ }^{26} \mathrm{Di}$ artikelnya, dia menyebutkan bahwa sosok pemimpin yang hari ini, diduga tidak dapat membaca Alquran karena tidak memiliki latar pondok pesantren. Dari sini jelas, ada upaya sadar mengkonstruk bagaimana Alquran bisa hidup dan hadir dalam kehidupan masyarakat sebagai kebutuhan, landasan sikap, dan pola pikir untuk menegakkan nilai-nilai keagamaan, dalam dimensi dan ruang yang berbeda-beda.

\section{b. Ayat-ayat Alquran sebagai Ritual dan Seremoni}

Selain ayat-ayat Alquran sebagai rujukan atau sumber ajaran, baik dalam bentuk pengajian tafsir

sebagaimana dikutip dalam A Rafiq Zainul Mun'im, "Alquran dalam Kehidupan Masyarakat (Studi tentang Simbolisasi dan Pemaknaan Ayat-ayat Alquran bagi Masyarakat Probolinggo Jawa Timur), Disertasi (Surabaya: Program Pascasarjana IAIN Sunan Ampel Surabaya, 2013), 139.

${ }^{26}$ Lihat Tulisan Husen, "Masih terkait Pemimpin Perempuan di Kabupaten Probolinggo dalam bingkai Pandangan Islam; diakses kembali melalui http://sekelumitinfo.wordpress.com pada 23 juni 2017 maupun melalui majelis taklim, di Probolinggo ayat-ayat Alquran juga dijadikan sebagai elemen ritual. Ayat-ayat Alquran menjadi elemen penting, dibaca dalam forum-forum seremonial, tadarrus, khataman, tahlilan, istighotsah, walimah, dan hajatan. Di Probolinggo, Alquran juga dibaca secara rutin di setiap kegiatan masyarakat dan diajarkan di tempat-tempat ibadah, bahkan di rumah-rumah, sehingga menjadi simbol ritual. Apalagi di pesantren-pesantren, Alquran menjadi bacaan wajib. Alquran senantiasa dihafalkan oleh sebagian santri, baik secara utuh maupun sebagiannya, meski ada juga yang hanya menghafal ayat-ayat dan surat-surat tertentu untuk kepentingan bacaan dalam shalat dan acara tertentu. Sebagaimana yang terjadi di Dusun Kebonagung Desa Sidodadi, terdapat komunitas masyarakat yang getol membaca Alquran seperti melakukan khatmi Alquran. Uniknya, kegiatan ini dilakukan di beberapa mushala dusun secara bergiliran. Kegiatan ini telah dilakukan lebih dari 7 (tujuh) tahun yang lalu dan tetap bertahan hingga saat ini tanpa harus terikat oleh bulan Ramadhan dan dilaksanakan selama tiga jam pada malam hari setelah salat Isya. ${ }^{27}$

Jamaah yang mengikuti kegiatan ini tidak terikat oleh umur namun kebanyakan dari mereka adalah masyarakat yang tidak memiliki kesibukan di malam hari. Lebih dari itu, dalam sebuah wawancara, Husni (warga masyarakat Kraksaan Probolinggo) menyatakan: "Ayat-ayat Alquran sering dibaca oleh para Qori' dalam acara-acara khusus yang berkaitan dengan peristiwa-peristiwa tertentu, khususnya dalam acara hajatan, atau peringatan hari-hari besar Islam. Alquran senantiasa dibaca dalam acara-acara kematian seseorang, bahkan pasca kematian dalam tradisi yasinan, tahlilan, istighotsah, dan lain sebagainya." ${ }_{28}$

Selain itu, dalam hal ritual peribadatan, ayat-ayat Alquran dijadikan wirid dalam bilangan tertentu untuk memperoleh kemuliaan atau keberuntungan dengan jalan riyâdhah. Misalnya, ketika menghendaki sesuatu, ada masyarakat yang membaca surat yasin sebanyak 41 kali dalam satu kali majlis. Ada juga yang membaca surat al-Ikhlas

${ }^{27}$ Dikutip dari berbagai informan, lebih lanjut lihat A Rafiq Zainul Mun'im, “Alquran dalam Kehidupan Masyarakat, h.150.

${ }^{28}$ A Rafiq Zainul Mun'im, “Alquran..., h. 151. 
11 kali setiap selesai salat shubuh dan maghrib. Di samping itu ada juga yang mengamalkan ayat kursi yang dibaca setiap selesai salat 5 waktu, dan lain sebagainya. ${ }^{29}$ Oleh karenanya, ayat-ayat Alquran di Probolinggo sangat hidup dalam beragam bentuk simbolisasi dan pemfungsiannya. Setiap ritual umat Islam di Probolinggo selalu menggunakan ayat-ayat Alquran sebagai bacaan dalam ritual tersebut. Meskipun terdapat bacaan kalimat-kalimat Thoyyibah yang lain, misalnya: subhâna Allâh, alhamduli Allâh, astaghfiru Allâh, lâ ilâha illa Allâh, allâhu akbar, shalawât, dan lain sebagainya; namun bacaan ayat-ayat Alquran tetap selalu ada dan disertakan dalam ritual tersebut, terutama bacaan surat al-Fatihah.

Para pembaca ayat-ayat Alquran di Probolinggo boleh jadi terinspirasi untuk mengungkapkan gambarannya sendiri tentang Alquran. Rasulullah Saw bersabda, "Alquran adalah jamuan Tuhan. Rugilah yang tidak menghadiri jamuan-Nya; dan lebih rugi yang hadir tetapi tidak menyantapnya..." 30 Dengan membaca ayat-ayat Alquran, seorang muslim (termasuk dalam masyarakat Probolinggo) hatinya menjadi tenang dan damai. Seorang informan menyatakan: "Ketika membaca ayat-ayat Alquran, hati menjadi tenang dan tenteram. Hal itu tidak terkait dengan satu atau beberapa ayat, atau surat tertentu, tetapi sembarang ayat". ${ }^{31} \mathrm{Hal}$ ini merupakan sesuatu yang tidak dapat dibantah. Membaca Alquran mendatangkan kebahagiaan dan ketenangan hati. Apalagi kalau membaca ayatayat tentang ketakwaan yang akan dibalas oleh Allah dengan surga-Nya, dimudahkan rezekinya, urusannya, dan lain-lain. Semakin sering membaca dan menyelami kandungannya hati semakin tenang dan bahagia, bahkan rasa percaya diri semakin tinggi. Sebaliknya, semakin mengabaikan Alquran, maka hati semakin gundah, pusing, dan gelisah.

\section{c. Ayat-ayat Alquran sebagai Seni Kaligrafi}

Secara observasional, ketika memasuki Kecamatan Tongas-Sumberasih Probolinggo,

\footnotetext{
${ }^{29}$ A Rafiq Zainul Mun'im, “Alquran..., h.151

${ }^{30}$ M. Quraish Shihab, Membumikan al-Qur'an: Fungsi dan Peran Wahyu dalam Kehidupan Masyarakat, (Bandung: Mizan, 1998), Cet.ke-18, h.34

${ }^{31}$ Wawancara dengan Hj. Luthfiyah, pada tanggal 22 Juni 2012 sebagaimana dalam A Rafiq Zainul Mun'im, “Alquran dalam Kehidupan Masyarakat, h. 153.
}

terdapat Masjid al-Syuhada yang terletak di Jl. Raya Banjarsari Probolingggo, maka suguhan ornamen kaligrafi Alquran bisa ditemukan di atas mihrab dan kubah masjid tersebut. ${ }^{32}$ Alasannya sebagaimana diungkapkan oleh Thoyyibul Farouh:

"Tidak hanya nilai keindahan yang diberikan oleh kaligrafi dari ayat-ayat Alquran, tetapi nuansa spiritual juga ada dalam kaligrafi tersebut. Misalnya, ketika kita melihat tulisan ayat-ayat Alquran, kita menjadi ingat kepada Allah Swt. Dengan demikian tulisan kaligrafi ayat-ayat Alquran menjadi media untuk ingat dan beribadah kepada Allah Swt, disamping untuk keindahan." 33

Seni penulisan Alquran merupakan seni Islam yang par-excellence. Seni kaligrafi menjadi sentral seni peradaban Islam, tak dapat dipisahkan dari Alquran. Untuk itu tujuan penulisan teks suci Alquran sebagai hiasan seni merupakan visualisasi inspirasi spiritual dan artistik yang berhubungan dengan penulisan dan pembacaan teks Alquran. Untuk mempertahankan inspirasi spiritual dan artistik ini, Hisbullah, salah satu masyarakat Probolinggo telah melakukan penulisan teks Alquran karena cita-citanya membentuk peradaban Qur'âni di Kabupaten Probolinggo. Keunikan teks kaligrafi seluruh ayat Alquran ini adalah karena masih sangat jarang seorang penulis kaligrafi yang membuat atau menulis Alquran secara utuh dengan tulisan tangannya sebagai tulisan Alquran pertama yang ditulis tangan oleh masyarakat Probolinggo.

Ada juga yang beranggapan jika seni ada ajaran keindahan adalah representasi integrative dari Islam itu sendiri. Salah satu masyarakat

${ }^{32}$ Adapun simbol ayat Alquran yang digunakan sebagai ornament di atas mimbar atau mihrab adalah Q.S. al-Mu'minûn [23]: 1-6 dan Q.S. al-'Ankabût [29]: 45. Kemudian di sekeliling kubah, terdapat ornament kaligrafi dari ayat Alquran yang tersimbol dari Q.S. al-Jumu'ah [62]: 10-11; Q.S. al-Nûr [24]: 3638; Q.S. al-Taubah [9]: 108; dan Q.S. al-Taubah [9]: 18. Di Masjid Raudatul Muttaqin Banjarsari Sumberasih Probolinggo, juga terdapat simbol dari ayat Alquran yang ditorehkan ke dalam sebuah kaligrafi di atas mimbar masjid dengan menukil ayat Alquran Q.S. al-Nisa' [4]: 59. Sedangkan di Masjid Jami' Kota Probolinggo, terhadap ornament kaligrafi simbolik dari ayat Alquran yang membentang dari arah utara sampai selatan masjid dan berada di atas mihrab atau mimbar dengan berurutan dari Q.S. al-Isra'[17]: 78-80; Q.S. Âli Îlmrân, [3]: 102; Q.S. al-Jumu'ah [62]: 9; Q.S. al-Baqarah [2]: 153; dan Q.S. alMu'minûn [23]: 1-11.

${ }^{33}$ Dikutip dari A Rafiq Zainul Mun'im, “Alquran..., h. 159. 
Probolinggo, Faiqatul Hikmah, mengatakan: "Tulisan kaligrafi berupa ayat-ayat Alquran menurut saya itu sesuai dengan ajaran Islam. Dasarnya adalah bahwa Islam itu indah dan suka keindahan. Seni kaligrafi berupa ayat-ayat Alquran adalah bagian dari keindahan, berarti sesuai dengan ajaran Islam. Dengan demikian, seni kaligrafi berupa ayat-ayat Alquran itu memberikan tambahan syiar Islam di rumah-rumah orang Islam, dan di tempat-tempat yang memajangnya." 34

Alasan lainnya ialah ornamen-ornamen tersebut merupakan sebuah tradisi. Hampir di semua rumah Muslim masyarakat Probolinggo terdapat tulisan ayat-ayat Alquran yang dipajang di dinding rumahnya. KH. Ramzi Al Amiri Mannan mengatakan:

"Saya kira dasar dari itu adalah keindahan. Islam suka keindahan, jadi Islam tidak melarang untuk menjadikan ayat-ayat Alquran sebagai bagian dari seni keindahan. Kaligrafi di rumah dengan tulisan ayat-ayat Alquran itu banyak maslahatnya. Misalnya, dengan adanya tulisan itu, ketika orang membaca, maka dia akan ingat Allah. Atau makhluk halus yang suka mengganggu orang Islam tidak berani atau tidak betah di rumah yang ada tulisan ayat Alquran, disamping nilai-nilai keindahan yang dihasilkan. 35

Dengan demikian, simbolisasi ayat-ayat Alquran dalam bentuk seni kaligrafi, baik yang ditulis, diperjual belikan, dan dipajang di rumahrumah serta beberapa tempat umat Islam menjadi media interaksi antara hamba dan Tuhan. Terkadang juga menjadi media ienteraksi antara seseorang dengan realitas di sekitarnya, ketika ayat-ayat yang dipajang di rumahnya berkaitan dengan kondisi realitas masyarakat tersebut.

\section{d. Ayat-ayat Alquran sebagai Sarana Mistis}

Pada masyarakat Probolinggo, Alquran tidak hanya dijadikan sumber tafsir, tetapi Alquran dijadikan sebagai sarana mistis. Alquran dijadikan media jimat, rajah, dan bentuk-bentuk ritual mistis yang lain. Misalnya, ayat Alquran untuk jimat kekebalan tubuh dari senjata tajam, untuk pengasihan, untuk menyelinap dari penglihatan

${ }^{34}$ A Rafiq Zainul Mun'im, “Alquran.., h. 162.

${ }^{35}$ A Rafiq Zainul Mun'im, “Alquran..., h. 163. orang, dan lain sebagainya. Salah seorang kiai di PP Nurul Jadid Paiton Probolinggo, KH. Ramzi al Amiri Mannan, ketika ditanya mengenai jimat dari ayat Alquran mengatakan:

"Saya sering membuatkan jimat dari ayat Alquran untuk seseorang yang bertamu, kalau memang ia meminta. Selama saya bisa, maka saya buatkan sesuai dengan permintaan. Misalnya, saat ini saya memakai jimat kebal dari senjata tajam. Jimat tersebut sudah teruji pada diri saya, artinya: kalau saya memakai jimat tersebut, maka dengan izin Allah saya tidak tembus atau saya kebal dari senjata tajam apapun. Nah, tamu-tamu yang tahu itu, banyak yang meminta dibuatkan jimat kebal tersebut. Ya saya buatkan, asalkan tidak digunakan untuk sombong dan menjahati orang." 36

KH Ramzi al Amiri, ketika diwawancara, mempraktikkan kekebalan tubuhnya dengan membacok tangannya, dan terbukti benar bahwa ia kebal dari pedang yang dibacokkan ke tangannya dengan izin Allah melalui jimat yang dipakainya. Menurut Kiai Ramzi, pedang yang dipakai untuk membacok tangannya juga mengandung jimat. Kata dia, kalau orang terluka terkena pedang tersebut, maka tidak ada obat penawarnya, orang yang terkena akan titanus. Tangan dia yang terkena bacokan, meskipun tidak luka, tapi akan terasa sakit sampai dua hari, lantaran jimat yang dikandung oleh pedang yang mengenai tangannya tersebut.

Selain untuk maksud-maksud tertentu, pengamalan atau penggunaan jimat menurut Kiai Hefni juga bertujuan untuk tawasul kepada sang guru. Biasanya, kalau mau memakai jimat tertentu, ada amalan berupa kiriman Surat alFâtihah kepada seorang guru atau orang yang memberikan ijazah. Dalam komentarnya, Kiai Hefni mengatakan:

"Seseorang yang memakai jimat-apakah itu dari ayat Alquran atau tidak- sebenarnya disamping sebagai sarana untuk mencapai tujuan tertentu, juga sebagai sarana untuk tawasul kepada gurunya. Dalam artian, seseorang yang memakai amalan atau jimat tertentu dari seorang guru, sebelum dia memakai jimat tersebut atau mengamalkan

${ }^{36}$ A Rafiq Zainul Mun'im, “Alquran..., h. 168. 
amalan tersebut, diawali dengan tawasul kepada guru yang memberikan ijazah. Tawasul itu terkadang berupa kiriman surat al-Fatihah. Jadi pengamalan jimat atau ijazah tertentu itu terkadang untuk menyambungkan diri dengan sang guru." 37

Dengan demikian, di masyarakat Probolinggo, Ayat-ayat Alquran dijadikan oleh sebagian umat Islam sebagai jimat, jampi-jampi, terapi jiwa, pelipur duka dan lara, untuk mendoakan pasien yang sakit, bahkan untuk mengobati penyakitpenyakit tertentu. Potongan ayat-ayat Alquran dijadikan jimat yang dapat dibawa pergi ke mana saja oleh pemiliknya sebagai perisai atau tameng, tolak balak atau menangkis serangan musuh dan unsur jahat yang lain. Ayat-ayat Alquran juga dijadikan wirid dan dzikir untuk mengusir jin, makhluk jahat, ruh gentayangan atau fenomena kegaiban yang lain. Ayat-ayat Alquran juga dijadikan bacaan dalam menempuh latihan bela diri oleh perguruan bela diri berbasis Islam agar memperoleh kekuatan tertentu setelah mendapatkan maunah dari Allah Swt. Alquran juga dijadikan bacaan para praktisi-terapis untuk menghilangkan gangguan psikologis dan pengaruh buruk lainnya (jin) dalam praktik ruqyah dan penyembuhan alternatif. Dengan begitu, Alquran dalam konteks masyarakat Probolinggo sangat hidup dalam ragam bentuk simbolisasi yang bermakna di masyarakat.

Bagi beberapa kalangan masyarakat, ilmu mistik adalah sebuah fenomena yang sangat kental dalam tradisi masyarakat tertentu. Baik masyarakat Muslim maupun non Muslim. Biasanya, mereka adalah masyarakat yang garis pemikirannya masih bukan burhani, lebih mengedepankan hati nurani daripada akal pikiran. Dalam hal ini, beberapa contoh aplikatif mengenai ayat Alquran yang telah diperlakukan secara sosial budaya adalah terkait dengan mistik sebagai sebuah respon masyarakat terhadap Alquran dengan menggunakan tashdiq bi alqalb sehingga ayat-ayat Alquran diyakini mereka sebagai sebuah jampi dan mantra. Keyakinan ini telah terjadi selama berabad-abad lamanya.

Dalam penggalian data seputar hal tersebut,

${ }^{37}$ A Rafiq Zainul Mun'im, “Alquran ..., h. 171. peneliti juga menggunakan sebuah kitab pusaka salah satu masyarakat Probolingo dalam bentuk naskah "manuskrip" namun masih "berumur muda," karena ditulis pada masa di mana telah banyak bermunculan mesin ketik, komputer dan alat cetak. ${ }^{38}$ Naskah ini adalah sebuah kumpulan catatan yang terdiri dari doa, hizb, jampi, mantra, dan sebagainya. Di dalam naskah ini terdapat beberapa ayat yang sudah ditentukan penggunaan dan fungsinya, misalnya; Q.S. AlBaqarah [2]: 165 dan Q.S. Âli 'Imrân [3]: 14. Kedua ayat ini dibaca dalam rangka mendapatkan mahabbah (dicintai/dihormati) bagi segenap umat manusia. Cara yang dilakukan adalah dengan membaca ayat di atas sebanyak tujuh kali dengan membaca Fatihan sebagai bentuk tawassul terlebih dahulu kepada beberapa syaikh. Ayat Alquran lainnya adalah Q.S. al-Hadid [57]: 25 yang bertujuan untuk melanggengkan pernikahan dan dilakukan oleh orang yang akan melaksanakan akad nikah dengan cara dibaca sebanyak tujuh kali secara istiqamah. Kemudian pada waktu akad nikah, ayat ini dibaca sebanyak tujuh kali sembagi memegang paku sebannyak tujuh buah dan djatuhkan ketika pembacaan akad nikah telah selesai. 39

Dari naskah itu dan beberapa ayat yang direpresentasikan memiliki kelebihan tersebut, pada dasarnya, sekedar wujud penafsiran dan keyakinan yang dihadirkan oleh para tokoh agama di daerah sekitar. Para kiai dan mereka yang concern terhadap aspek kesejarahan terbentuknya Alquran sangat memahami bagaimana Alquran digunakan oleh Nabi untuk keluar dari persoalanpersoalan tertentu. Pemahaman terhadap sejarah itu, dikristalisasi sebagai sebuah keyakinan di masyarakat, sehingga membuat masyarakat lebih percaya diri untuk menghadapi orang lain. Namun demikian, sekali lagi ingin penulis tegaskan bahwa, tidak semua orang mampu dan bisa memahami aspek kelebihan Alquran

\footnotetext{
${ }^{38}$ Naskah Kitab Pusaka, (t.tp.: t.p., t.th.)

${ }^{39}$ Ada juga ayat Q.S. al-Nisa'[4]: 84 yang apabila ayat ini dibaca sebanyak beberapa kali, maka ayat tersebut memiliki faedah sebagai baju kurung atau perisai bagi seseorang dari berbagai senjata tajam, pukulan mematikan, dan sebagainya. Jadi, perisai batin ini diyakini dapat membuat tubuh tidak terkena pukulan karena semanya akan memantul seperti karet dan membutuhkan waktu yang relatif lama.
} 
berdasarkan pada dimensi tersebut. Ruang hidup Alquran di masyarakat awam, umumnya sekedar manifestasi dari kewajiban untuk membaca dan mengharap pahala dan syafaat dalam persoalanpersoalan tertentu.

\section{Makna Simbolik Alquran di Probolinggo}

Dari data di atas, simbolisasi ayat-ayat Alquran sebagai sumber ajaran dan pemikiran serta praktik keagamaan sangat tampak dalam kehidupan masyarakat Probolinggo, terutama di daerah-daerah sekitar pesantren dan masjid. Bagi penulis, simbol merupakan kiasan atau gambaran tentang dunia nyata, baik dalam kenyataan maupun pada tingkatan ide. Dalam konteks Probolinggo, interpretasi pertama penulis terhadap simbolisasi ayat-ayat Alquran adalah sebagai bentuk dan petunjuk bagi perilaku orang-orang Probolinggo dalam memfungsikan Alquran. Simbol merupakan alat bantu yang dapat menggerakkan masyarakatnya..$^{40}$ Simbolisasi Alquran dalam bentuk kajian tafsir dan majelis taklim mencerminkan bahwa masyarakat Probolinggo menjadikan Alquran sebagai sumber pemikiran, ajaran, dan praktik dalam kehidupan nyata.

Kedua, masyarakat Probolinggo juga menghidupkan ayat-ayat Alquran dalam bentuk ritual dan seremoni. Bentuk-bentuk simbolisasi semacam itu telah mempengaruhi masyarakat Probolinggo untuk semakin berperilaku menghidupkan Alquran. Ketiga, dalam kehidupan masyarakat Probolinggo, simbolisasi ayat-ayat Alquran juga diwujudkan dalam bentuk seni kaligrafi, tilawati, dan lain sebagainya. Hal itu jelas mengandung makna tertentu. Ketika ayatayat Alquran dijadikan simbol dalam bentuk seni kaligrafi, maka disamping mengandung makna keindahan atau nilai estetika, juga mengandung makna spiritual, yakni sebagai sarana mengingat Allah Swt dan menambah ketenangan batin. Keempat, penafsiran terhadap fungsi dan peranan Alquran akan tambah lebih hidup apabila ayat-ayat

40 Pemaknaan di atas hampir sama dengan asumsi yang dibuat oleh Irwan Abdullah terkait simbol Alquran di masyarakat. Lihat Irwan Abdullah, Simbol, Makna dan Pandangan Hidup Jawa: Analisis Gunungan pada Upacara Garebeg (Yogyakarta: Balai Kajian Sejarah dan Nilai Tradisional, 2002), h. 12.
Alquran dijadikan sebagai sarana jimat atau mistis yang lain. Pasalnya, mereka yang menggunakan jimat tersebut, serta ayat-ayat Alquran yang dikumpulkan, sudah tentu dipahami memiliki maksud dan aspek kesejarahan tertentu. Para kiai pun acapkali menanyakan terlebih dahulu apa masalah dan tujuan meminta jimat, jampi, dan rajah tersebut.

Dari pembacaan reduktif diatas terlihat bagaimana masyarakat Probolinggo memaknai simbol-simbol atau simbolisasi ayat-ayat Alquran dalam perilaku kehidupan mereka. Simbolisasi ayat-ayat Alquran oleh masyarakat Probolinggo, ternyata tidak hanya memiliki satu arti, tetapi bisa beberapa arti yang-dalam bahasa Turner- disebut dengan istilah multivocal atau polysemy.Turner menggambarkan bahwa satu warna merupakan simbol dari beberapa konsep. Warna putih adalah simbol dari kesuburan, kemurnian, kesehatan, dan nasib baik; warna hitam adalah simbol dari kotoran, kesedihan, dan sesuatu yang tidak baik; warna merah sebagai simbol darah, keberanian, dan bahaya. ${ }^{41} \mathrm{Jadi}$, simbolisasi ayat-ayat Alquran yang diwujudkan oleh masyarakat Probolinggo dalam beragam aktifitas memiliki makna multivocal (mengandung makna lebih dari satu).

Selain itu, formalitas ayat-ayat Alquran yang difungsikan dalam ragam bentuk aktifitas, telah membentuk strukturnya sendiri di masyarakat Probolinggo. Apa yang nampak dalam masyarakat Probolinggo dalam memperlakukan Alquran dalam kehidupannya yang nyata, maknanya dapat dipahami dari struktur luar dan struktur dalam. Struktur luar nampak dari tradisi masyarakat Probolinggo yang menjadikan ayat-ayat Alquran sebagai bacaan dalam kegiatan tafsir Alquran, majelis taklim, ritual peribadatan, ornamen kesenian, dan pembuatan jimat. Sementara struktur dalamnya dapat dipahami dari maksud dan tujuan masyarakat Probolinggo dalam beragam aktifitas yang menggunakan ayat-ayat Alquran sebagai komponennya. Pemaknaan Alquran dalam kehidupan masyarakat di Probolinggo ini

${ }^{41}$ Victor W. Turner, Betwixt and Between; The Liminal Period in Rites the Passage, Symposium Paper on New Approaches of Study of Religion, Vol 4 No 20 Tahun 1964, h. 12 
dapat dipahami lebih mendalam melalui kajian strukturalisme Levi-Strauss ini, dengan asumsi bahwa bagaimana masyarakat memperlakukan simbol dari ayat-ayat Alquran sebagai sebuah fenomena budaya dapat ditelusuri secara mendalam melalui pemaknaan mereka terhadap simbol tersebut. Sedangkan pemaknaan terhadap simbol dari ayat-ayat Alquran ini dapat ditelusuri melalui struktur terdalamnya yang dapat diungkap melalui pemaparan-pemaparan masyarakat secara maknawi dalam "kesadaran" atau "ketidaksadaran" mereka, sehingga segala fenomena yang terjadi dapat diketahui melalui makna sejatinya tanpa ada rekayasa sedikitpun. ${ }^{42}$

Dalam hal ini, pemaknaan berdasarkan struktur luar (surface structure) yang bisa ditelisik adalah sebagai berikut:

Tabel 1.1

Surface-Structure of Qur'ân in Probolinggo

\begin{tabular}{ll}
\hline Surface Structure & Meaning of simbolization \\
\hline Kasus pembelajaran & Dalam kasus ini, penulis ingin me- \\
kitab Tafsir bi al Imla' & nyatakan bahwa, apa yang dilakukan \\
di Pondok Pesantren & pengasuh untuk mentransmisi-kan \\
Nurul Jadid Paiton. & $\begin{array}{l}\text { Alquran dilakukan dalam bentuk } \\
\text { intense yang kuat. Sehingga, tidak } \\
\text { jarang ada banyak catatan tangan dia } \\
\text { di dalam kitab para santri. }\end{array}$
\end{tabular}

Kasus pembelajaran Pada kasus ini, KH Zuhri Zaini ingin KH. Zuhri Zaini di menempatkan Alquransebagai Musholla Riyadlus Sumber ajaran Islam yang relevan Sholihin dengan kondisi zaman. Maka improvisasi dan pengayaan makna dari Tafsir yang ijmali menjadi sangat penting. Lebih-lebih bagi mereka satu tahap lagi, akan terjun ke masyarakat (baca; mahasiswa-santri).

Kasus penafsiran Ustadz Masduki, mengacu kepada naskah berjudul al-Muqtathafat yang dijadikan rujukan dalam pembelajaran Tafsir.

Dalam karya al-Muqtathafat tersebut kerangka penafsiranny masih terbangun dalam bentu relasi guru dan murid pada proses penerjemahannya. Tidak ada indicator yang spesifik, misal tujuan akhir dan awal dalam proses penyampayannya.

Diskursus tafsir politik Dialog dalam website ini menjadi ajang Probolinggo, terdapat perdebatan masyarakat Probolinggo hubungan antara Q.S. al-Nisa' [4]: 34 dengan penegasan Husen tentang kemampuan Calon Bupati membaca Alquran.

\begin{tabular}{ll}
\hline $\begin{array}{l}\text { Pemanfaatan Alquran } \\
\text { dalam kegiatan }\end{array}$ & $\begin{array}{l}\text { Dalam hal ini, Alquran berhubungan } \\
\text { dengan makanan dan minuman yang } \\
\text { seremonial atau } \\
\text { ritual, dalam hal ini }\end{array}$ \\
$\begin{array}{l}\text { disuguhkan di Mushala sebagai bagian } \\
\text { lebih ditekankan pada }\end{array}$ & $\begin{array}{l}\text { Tradisi tempat yang bergiliran juga } \\
\text { kasus komunitas }\end{array}$ \\
masyarakat & tidak hadir di tempat A tetapi hadir di \\
& tempat B, sehingga tradisi seremonial \\
& ini dapat tetap berjalan.
\end{tabular}

Kaligrafi ayat Alquranyang ada di atas mihrab Masjid di Probolinggo

Tujuannya adalah agar mudah dibaca oleh jama'ah yang ada di masjid tersebut.Penggunaan warna putih dan hijau tua menjadi dominasi dalam penulisan seni kaligrafi ini, sehingga kesan ke-NU-an nya menjadi sangat tampak.

Simbol-simbol ayat Alquran sebagai sarana mistis sebagaimana dalam naskah pusaka dan cerita KH. Romzi

Dalam kasus ini, maka keberadaan ayat-yat tersebut ditampilkan sebagai bagian integral untuk meningkatkan keyakinan keislaman dari sudut pandang serta dimensi mistis.

Sedangkan pemaknaan berdasarkan struktur dalam (deep structure) dari pemaknaan simbolisasi ayat-ayat Alquran pada masyarakat probolinggo adalah sebagai berikut:

Tabel 1.2

Deep-Structure of Qur'ân in Probolinggo

\begin{tabular}{l}
\hline Deep Structure \\
\hline Kasus pembelajaran \\
kitab Tafsir bi al Imla' \\
di Pondok Pesantren \\
Nurul Jadid Paiton.
\end{tabular}

Meaning of simbolization

konteks pengajian Alquran dengan judul Tafsir Alquran bi al-Imla', sebagaimana judul karyanya, maka keberadaan ayat-ayat Alquran beserta tafsirnya, tanpa disadari telah menjadi media pembelajaran tulis menulis arab untuk para santri di pesanten tersebut. Kegiatan tulis menulis Arab, adalah budaya pesantren pada umumnya sehingga untuk mendapatkan keterampilan tersebut, maka KH Zaini Mun'im sebagai sang guru sekaligus mufassir di pesantren tersebut mendiktekan ayat-ayat Alquran beserta tafsirnya untuk di tulis ulang secara ilma' dan dibaca kembali agar mendapatkan pembetulan tulisan.

Kasus pembelajaran KH. Zuhri Zaini di Musholla Riyadlus Sholihin

Apa yang dilakukan KH. Moh Zuhri Zaini adalah keharusan sekaligus kebutuhan sang kiai untuk memposisikan dirinya secara arif dan bijaksana khususnya dalam kegiatan kemasyarakatan dan pendidikan yang berkaitan dengan non muslim. Sifat yang inklusif dari sang Kiai ini dibuktikan dengan sebuah hasil penelitian' yang menyatakan bahwa dalam kiprah dan kepemimpinan $\mathrm{KH}$. Moh Zuhri Zaini, telah melakukan jalinan kerjasama dengan non muslim, khususnya pendidikan bahasa Inggris yang didatangkan dari AVI (Australian Volounteer for Indonesia) selama dua tahun dan pembelajaran bahasa Mandarin yang gurunya didatangkan setiap tahun dari China untuk Nurul Jadid oleh Kedutaan China di Jakarta.
42 Levi Strauss, Structural Anthropology, terj, Claire Jacobson \& B G Schoepf (New York; Basic Book Inc, 1963), 


\begin{tabular}{ll}
\hline Kasus penafsiran & Dalam kasus penafsiran Ust. Masduki, \\
Ustadz Masduki, & maka dapat ditelusuri berdasarkan \\
mengacu kepada & latar belakang sang ustad sebagai \\
naskah berjudul al- & guru lulusan Fakultas Tarbiyah \\
$\begin{array}{l}\text { Muqtathafat yang } \\
\text { dijadikan rujukan dalam }\end{array}$ & sekaligus aktifis MWC NU Kecamatan \\
pembelajaran Tafsir. & di rumahnya. Sebagai seorang guru \\
& tafsir, maka Ust. Masduki harus \\
& melakukan tugas dan kewajibannya. \\
& Tetapi di sisi lain, kiprahnya di MCW \\
& NU yang selalu berkhidmat dan \\
& dituntut untuk mensedekahkan \\
& harta benda dan tenaga sekaligus \\
& keadaannya sebagai pedagang yang \\
& selalu menghitung dan mengkalkulasi \\
& untung rugi dari sebuah perdagangan \\
& telah mempengaruhi pola pikirnya \\
dalam menghitung untung rugi dalam & beramal. \\
\hline
\end{tabular}

Diskursus tafsir politik Probolinggo, terdapat hubungan antara Q.S. al-Nisa'[4]:34 dengan penegasan Husen tentang kemampuan Calon Bupati membaca Alquran.

Dalam diskursus politik, suasana politik di Probolinggo menjadi tidak stabil karena selama dua periode telah dipimpin oleh Bupati Hasan Aminuddin dan pada periode berikutnya calon bupati yang diusung adalah istri sang Bupati. Penolakan terhadap calon bupati yang direpresentasikan dengan sebuah simbol dari Q.S. al-Nisa'[4]: 34 beserta pro kontranya adalah ungkapan ketidak setujuan blogger terhadap calon bupati tersebut. Selain itu, ungkapan dalam blog yang menyangsikan keberadaan calon bupati dengan indikator kepemimpinan yang dihubungkan dengan kemampuannya membaca Alquransemakin memperkuat ketidak cocokan mereka terhadap Tantri, karena telah menjadi isu publik di Probolinggo adalah mantan petugas Bank asal Surabaya, sehingga memiliki nilai negatif di mata masyarakat. Oleh sebab itu, kutipan tentang "kemampuan membaca Alquran” adalah wujud dari penolakan tersebut.

Pemanfaatan

Alqurandalam kegiatan seremonial atau ritual, dalam hal ini lebih ditekankan pada kasus komunitas masyarakat

Dengan pengajian tadarus Alquran ini, mereka bisa disibukkan dengan pengajian tersebut dan secara otomatis, hubungan silaturrahim dengan sesama masyarakat jadi terbangun.Tetapi dalam konteks masyarakat dusun, terutama di waktu menjelang malam dengan beberapa suguhan makanan dan minuman di mushala yang bisa di makan dan di minum sambil lalu membaca Alquran, menjadi spirit dan motivasi tersendiri bagi mereka untuk tetap berkumpul, kendati harus membaca Alquran.

Kaligrafi ayat Alquran yang ada di atas mihrab Masjid di Probolinggo

\begin{abstract}
Simbol-simbol ayat Simbol-simbol ayat Alquran sebagai Alquran sebagai sarana mistis sebagaimana dalam naskah pusaka dan cerita KH. Romzi sarana mistis menunjukkan bagaimana masyarakat memperlakukan Alquran berdasakan kebutuhan pragmatis mereka. Hal ini bisa semakin memperkuat posisi ayat Alquran dalam kehidupan masyarakat tersebut. Kendati sekedar dirapalkan dan bernuansa mistis, hal itu menjadi i'tikad bahwa ayat tersebut memiliki nilai tepat guna dan salih li kulli zamân wa makân.
\end{abstract}

Berdasarkan pada cara simbol ditampilkan sesuai dengan kerangka berfikir V. W. Turner dan bagaimana dimensi kesadaran strutuktural yang penulis pinjam dari cara berfikir Levi-Strauss, maka menilai pembudayaan simbol ayat-ayat Alquran dalam beragam aktifitas di masyarakat Probolinggo dapat dipahami sebagai suatu kondisi secara tampilan mayarakat probolinggo masih berperilaku seperti kaum santri, masyarakat dengan tingkat religiusitas yang baik, dan sangat kuat memegang Alquran sebagai pegangan hidup mereka. Lebih-lebih, diakui atau tidak, mayoritas masyarakat Probolinggo berkultur Nahdhiyin (pengikut organisasi Keislaman NU) dengan menjadikan ayat-ayat Alquran sebagai bagian terpenting dari tradisinya dan menjadi bagian yang tidak bisa dipisahkan dalam aktifitas kehidupan.

\section{Kerangka Analisis: Posisi Alquran dalam Kehidupan Sehari-hari}

Selaras dengan landasan teori (baca; living Qur'ân/menghidupkan Alquran) serta kerangka teori yang digunakan berdasarkan pada pemikiran tokoh struktural antropologi di atas, maka penulis mengasumsikan jika; pertama, dalam upaya untuk menghidupkan Alquran dalam kehidupan masyarakat diperlukan cara pandang realistis terhadap fenomena yang berkembang, kemudian memberikan makna yang terkandung di balik Alquran itu sesuai fungsi-fungsinya dan lebih nampak di dalam kehidupan masyarakat. Jadi, realist-interpretation yang penulis maksudkan ialah makna Alquran disampaikan dan diobjektifasikan kepada ruang yang berdialektika dengan sendirinya di lingkup dinamika masyarakat. Di Probolinggo misalnya, disaat masyarakatnya masih memiliki ketaatan 
terhadap nilai-nilai Qurani, maka Alquran harus hadir dan mewarnai kehidupan mereka sesuai dengan intense masyarakat sekitar. Alquran dihadirkan sebagai manifestasi 'wujud tampak' nilai bentindak dan bersosialisasi. Alquran hadir sebagai ornament nilai yang memiliki daya mistis. Alquran hadir sebagai bagian dari peribadatan, semisal ayat-ayat yang dirangkum oleh ustaz Masduki sebagai amal baik yang dilipat gandakan, dan lain sebagainya.

Selanjutnya, interpretasi nyata terhadap Alquran melalui simbol dan pola interaksi, juga akan menghadirkan hikmah tersendiri terhadap keberadaan Alquran. Alquran menjamin akan adanya kedamaian jiwa bagi mereka yang membaca, mendengarkan, dan berupaya menggali makna-makna yang terselubung di dalam Alquran. Alquran yang dibacakan, dirituskan, serta diutamakan dalam acara-acara kemasyarakat harus dimaknai sebagai upaya mengharap ma'ûnah dan syafaat Tuhan akan kehidupan yang lebih diberkahi. Ketiga, menghadirkan penafsiranpenafsiran yang realis ini, secara tidak langsung, menjauhkan masyarakat dari mal-interpretasi terhadap Alquran yang digunakan sebagai landasan melakukan terorisme, penyebaran pemahaman radikalisme, sekaligus alat politik untuk menghegemoni masyarakat untuk memilih/tidak memilih calon tertentu. Kendati, di kalangan masyarakat awam hal tersebut masih sangat sering digunakan. Maka solusi keluar dari itu, selain kecenderungan membincangkan manfaat dan fadhâil al 'amal dalam membaca dan memahami Alquran, para tokoh-tokoh masyarakat harus bisa memberikan pemahaman yang benar dan utuh berdasarkan pada keilmuankeilmuan yang dimiliki.

Adapun terkait posisi penelitian ini terhadap riset-riset terdahulu, bagi penulis, memiliki dua kontribusi pasti-berasaskan pada kondisi masyarakat di Probolinggo. Pertama, penelitian ini menemukan bahwa selain konsepsi penafsiran yang realis dan disusun berdasarkan dialectical tension antara makna dan kebutuhan masyarakat, terdapat kelompok masyarakat Probolinggo yang juga menyadari pentingnya keberadaan Alquran di dalam kehidupan merekan; baik itu sebagai sumber ekonomi seperti yang ditmapilkan oleh para pengrajin kaligrafi Arab, atau sebagai wujud permintaan keselamatan dan kesaktian seperti yang dibungkus berbentuk jimat serta amalan rutin dalam kehidupan sehari-hari itu. Kedua, tentu, temuan unik ini, memberikan dimensi lain bahwa diskursus living Qur'ân tidak sekedar berhubungan dengan aktor dan mufasir yang memahami Alquran. Melainkan juga masyarakat biasa yang memiliki skill untuk mengkapitalisasi Alquran sehingga memiliki fungsi, mencetuskan simbol baru, sekaligus termanifestasi terhadap kehidupan sehari-hari dalam bentuk ritus dan mitologi yang diyakini. Misalnya, semaan Alquran yang diselenggarakan untuk menolong para pendahulu yang sudah meninggal di masyarakat Sidodadi Paiton Probolinggo.

Pada intinya, living Qur'ân berbasis pada realist-anthropologist approach semakna seperti apa yang ditampilkan oleh Sayyid Hossen Nasr dalam Islamic Art and Spirituality, dimana dia mengatakan bahwa ada nilai terkandung dibalik seni dan bangunan artifak keislaman. Hal yang paling sederhana untuk menginterpretasikan ialah dengan cara melihat spiritualisasi dibalik bingkai gambar, tulisan indah, hingga pada bangunan nyata yang dihasilkan. ${ }^{43}$ Dari sisi penafsiran, kerangka berfikir ini memberikan pola baru dimana seorang mufasir perlu memahami dinamika yang berkembang di masyarakat. Mereka tidak perlu memaksakan apa yang tidak dipahami masyarakat terkait dengan Alquran. Mereka tidak pelu juga menghadirkan diskursus yang muluk untuk menghidupkan Alquran. Cara interpretasi seperti ini, diungkapkan oleh Hasan Hanafi bahwa pemaknaan objektif terhadap Alquran sangat tergantung pada pemahaman seorang mufasir itu sendiri. Karena, sejatinya, tafsir (interpretasi) tidak selalu berhubungan dengan sumber pemaknaan terhadapnya, melainkan terhadap isi yang berhubungan dengan konteks. ${ }^{44}$ Maka tidak salah jika para kiai-kiai

${ }^{43}$ Sayyid Hossen Nasr, Islamic Art and Spirituality, (New York; State University of New York Press, 1987), h.xi

${ }^{44}$ Hassan Hanafi, Islam in the Modern World, Tradition Revolution and Culture, (Kairo: Anglo, 1995), h. 416.Menurut Hasan Hanafi, penafsiran itu perlu memihak pada realitas demi melakukan perubahan sosial, yakni tafsir harus bersifat solutif dan transformatif. Mengenai hal ini, Hanafi merumuskan 
di lingkungan Pondok Pesantren di Kabupaten Probolinggo lebih mengedepankan nilai-nilai kemuliaan hidup bersama Alquran dibandingkan menghadirkan diskursus baru yang coba dibaca oleh masyarakat urban.

\section{Penutup}

Pada kesimpulannya dari tiga runtutan fokus masalah tersebut di atas, pertama, fungsi-fungsi simbolisasi ayat-ayat Alquran pada masyarakat Probolinggo adalah sebagai berikut: a) ayatayat Alquran dijadikan sebagai sumber ajaran agama dalam pengajian tafsir, majelis taklim, bahkan dalam dialog politik sekalipun; b), ayatayat Alquran dijadikan sebagai elemen penting dalam kegiatan ritual dan seremoni; c), ayatayat Alquran dijadikan sebagai ornamen seni kaligrafi; d), ayat-ayat Alquran dijadikan sebagai sarana mistis. Berdasarkan fungsi-fungsi dari simbolisasi ayat-ayat Alquran di atas, Alquran hidup di masyarkat probolinggo sebagai: simbol referensial/dominan yang difungsikan berdasarkan pemahaman dan unsur pengetahuan yang melekat di dalamnya dan difungsikan dengan penuh kesadaran, serta simbol instrumental/ kondensasi yang difungsikan berdasarkan ketidaksadaran masyarakat atau berdasarkan dorongan-dorongan emosional, ketakutan, kegelisahan, kesenangan, keramahtamahan, atau tekanan-tekanan seksual.

Kedua, simbolisasi ayat-ayat Alquran menunjukkan perilaku orang-orang Probolinggo dalam memfungsikan Alquran. Ketika masyarakat Probolinggo menjadikan ayat-ayat Alquran sebagai sumber ajaran baik dalam kajian tafsir,

langkah-langkah yang mesti dilalui dalam penafsirannya. Pertama, seorang penafsir harus memiliki keprihatinan dan komitmen untuk melakukan perubahan atas kondisi sosial tertentu. Kedua, merumuskan tujuan penafsiran. Ketiga, menginventarisasi ayat-ayat yang terkait dengan tema yang menjadi kebutuhannya. Keempat, mengklasifikasikan ayat-ayat tersebut atas dasar bentuk-bentuk linguistiknya. Kelima, membangun struktur makna yang tepat dengan sasaran yang dituju. Keenam, mengidentifikasi problem aktual dalam realitas. Ketujuh, menghubungkan struktur ideal sebagai hasil deduksi teks dengan problem faktual melalui perhitungan statistik dan ilmu sosial. Kedelapan, menghasilkan rumusan praktis sebagai langkah akhir proses penafsiran yang transformatif. Lebih lanjut lihat Hassan Hanafi, "Method of Thematic Interpretation of the Qur'an "dalam Stefan Wild(ed.) The Qur'an as Text (Leiden-New York: El. Brill, 1996), 204-205. majelis taklim, dialog politik, maka sebenarnya masyarakat Probolinggo mempunyai maksudmaksud dan tujuan-tujuan tertentu. Formalitas ayat-ayat Alquran yang disimbolisasikan dalam ragam bentuk aktifitas, telah membentuk strukturnya sendiri di masyarakat Probolinggo. Berdasarkan struktur luarnya, maka pemaknaan didasarkan kepada keterhubungan antar kata atau antar unsur yang dapat dilihat secara inderawi, sementara struktur dalamnya dapat dipahami dari nilai-nilai substansial masyarakat Probolinggo dalam beragam aktifitasnya.

Ketiga, posisi pemaknaan dan simbolisasi ayat-ayat Alquran pada masyarakat Probolinggo berada dalam definisi tafsir realis, karena ayatayat Alquran yang disimbolkan dan dimaknai oleh masyarakat Probolinggo merupakan realitas pemahaman, sikap dan keterampilan yang berlaku dalam kehidupan masyarakat tersebut. Hal itu sejalan dengan teori Hasan Hanafi yang menyatakan bahwa penafsiran bukanlah sekadar upaya untuk membaca teks, namun lebih dari itu harus menjadi upaya transformatif dan solutif bagi problem sosial yang terjadi dalam kehidupan.

Dalam hal ini, ayat-ayat Alquran telah difungsikan sebagai unsur vital yang benar-benar penuh arti dan nilai guna bagi masyarakat; Ayat-ayat Alquran dalam kehidupan masyarakat memiliki beragam makna dan fungsi. Pemaknaan ayat-ayat Alquran tidak hanya bersifat teoritis tetapi juga praktis, tidak hanya berkutat pada penerjemahan teks-teks harfiyah, tetapi juga mengaitkan teks harfiyah dengan situasi dan kondisi riil kehidupan masyarakatnya. Dalam hal ini, pemaknaan ayat-ayat Alquran merupakan realitas pemahaman dan bukanlah sekadar upaya untuk membaca teks, namun menjadi upaya transformatif dan solutif bagi problem sosial yang terjadi dalam kehidupan. Oleh sebab itu, penafsiran Alquran pada masyakarat Probolinggo berdasarkan kepentingan praksis, baik dengan tashdiq bi al-qalb (meyakini dalam hati), iqrar bi allisân (menyuarakan atau mengurai) al-Qur'ân,dan 'amal bi al-arkan (menerjemahkan Alquran dalam bahasa sikap). 


\section{Pustaka Acuan}

Abdullah, Irwan, Simbol, Makna dan Pandangan Hidup Jawa: Analisis Gunungan pada Upacara Garebeg, Yogyakarta: Balai Kajian Sejarah dan Nilai Tradisional, 2002.

Abidin S. Zainal, Seluk-beluk Alquran, Jakarta; Rineka Cipta, 1992.

Ali, Muhammad, "Kajian Naskah dan Kajian Living Qur'ân dan Living Hadis", dalam Journal of Qur'ân and Hadith Studies, Vol. 4, No 2 Tahun 2015.

Arikunto, Suharsimi, Prosedur Penelitian Suatu Pendekatan Praktek, Jakarta: Rineka Cipta, Cet. ke-XI. 1998.

Atabik, Ahmad, "The Living Quran: Potret Budaya Tahfiz Alquran Nusantara”, dalam Jurnal Penelitian,Vol. 8 No 1 Februari 2014.

Bogdan dan Steven, Introduction to Qualitative Research; A Phenomenological Approach to The Social Sciences. New York: John Wiley \& Sons Inc., 1975.

Faizah, Nur, "Ayat-Ayat Tentang Relasi Laki-Laki Dan Perempuan Dalam Alquran (Analisis Struktural Levi-Strauss)", dalam Jurnal Al Ahwal, Vol 8, No 2 Tahun 2015.

Faizin, Hamam, "Mencium dan Nyunggi Alquran Upaya Pengembangan Kajian Alquran Melalui Living Qur'ân," dalam Jurnal Suhuf, Vol. 4 No 1, Tahun 2011.

Fauziyah, Siti, "Pemaknaan ayat Alquran dalam mujahadah: Studi Living Qur'ân di PP al Munawwir Krapyak komplek al Kandiyas", dalam Jurnal Penelitian, Vol. 8 No. 1 Tahun 2014.

Federspiel, Howard M, Kajian Alquran di Indonesia dari Mahmud Yunus Hingga Quraish Shihab, Bandung; Mizan, 1996.

Hackett, Rosalind I. J, Anthropology of religion, dalam John R. Hinnells. (ed) The Routledge Companion to the Study of Religion, London: Rutledge, 2005.

Hanafi, Hassan. "Method of Thematic Interpretation of the Qur'ân "dalam Stefan Wild (ed.) The Qur'ân as Text, Leiden-New York: El. Brill, 1996. , Islam in the Modern World, Tradition Revolution and Culture, Kairo: Anglo, 1995.

Husen, "Masih terkait Pemimpin Perempuan di Kabupaten Probolinggo dalam bingkai Pandangan Islam; diakses http://sekelumitinfo. wordpress.com pada 23 juni 2017

Mansur, M, Metodologi Living Qur'ân dan Hadis, Yogyakarta: Teras, 2007.

Miles \& Huberman, Qualitative Data Analysis. London: SAGE Publications, 1984.

Muhtador, Moh, "Pembacaan Alquran SuratSurat Pilihan di Pondok Pesantren Putri Daar al Furqon Anggalan Kudus (Studi Living Qur'ân)", dalam Jurnal Studi Ilmu-llmu Alquran dan Hadis, Vol. 15, No. 1, Januari 2014.

Mun'im, A Rafiq Zainul, “Alquran dalam Kehidupan Masyarakat (Studi tentang Simbolisasi dan Pemaknaan Ayat-ayat Alquranbagi Masyarakat Probolinggo Jawa Timur)," Disertasi. Surabaya: Program Pascasarjana IAIN Sunan Ampel Surabaya, 2013. , Tafsir Surat al-Fatihah KH. Zainul Mun'im. Yogyakarta: Forstudia kerja bareng PP. Nurul Jadid, 2004.

Mursid dan A. Rafiq Zainul Mun'im, Pendidikan Multikultural di Pondok Pesantren Nurul Jadid, Penelitian. Surabaya: Kopertais IV, 2010. Muttaqin, Khoirul, "Pengajian Tafsir Jalalain di Pondok Pesantren Nurul Jadid dalam Menjawab Problem Sosial-Keagamaan Kontemporer", Skripsi, Fakultas Ushuludin Jurusan Tafsir Hadis, IAIN Sunan Ampel Surabaya, Tahun 2009.

Muzakki, Akh. \& Masdar Hilmy, Dinamika Baru Studi Islam. Surabaya: Arkola, 2005.

Nasr, Sayyid Hossen, Islamic Art and Spirituality, New York; State University of New York Press, 1987.

Nasution, Metodologi Penelitian Naturalistik Kualitatif, Bandung: Transtinto, 1996.

Putra, Heddy Shri Ahimsa, "The Living Alquran: Beberapa Perspektif Antropologi", dalam Jurnal Walisongo, Vol. 20, No.1, Mei 2012.

Shihab, M. Quraish. Membumikan Alquran: Fungsi dan Peran Wahyu dalam Kehidupan Masyarakat, cet. ke-18. Bandung: Mizan, 1998.

Siswanto, Ali Hasan "Relasi Politik Kiai di Daerah Tapal Kuda Jawa Timur," Penelitian individu Dosen.Surabaya: Lembaga Penelitian IAIN Sunan Ampel, Tahun 2011.

Strauss, Levi, Structural Anthropology, terj, Claire Jacobson \& B G Schoepf, New York; Basic Book Inc, 1963. 
Syamsudin, Sahiron, "Ranah-Ranah Penelitian dalam Alquran dan Hadis" Kata Pengantar, dalam M. Mansur, Metodologi Living Qur'ân dan Hadis, Yogyakarta: Teras, 2007.
Turner, Victor W. "Betwixt and Between; The Liminal Period in Rites the Passage," Symposium Paper on New Approaches of Study of Religion, Vol 4 No 20 Tahun 1964. , Victor W. The Ritual Process; Stucture and anti-Structure. Chicago, tp, 1969. 